Chapter 8

\title{
Classification of Revenues of Health Care Financing Schemes (ICHA-FS)
}




\section{Introduction}

This chapter presents the concept of the revenues of health financing schemes (FS) and their classification. The accounting framework for health financing presented in Chapter 7 provides the conceptual basis for this chapter.

\section{Main concept}

A key set of information for policy analysis is i) how much revenue is collected; ii) in what ways is it collected; iii) from which institutional units of the economy are revenues raised for each particular financing scheme; and iv) which financing schemes receive those revenues. Health accounts should therefore provide information both about i) the contribution mechanisms the particular financing schemes use to raise their revenues, and ii) the institutional units of the economy from which the revenues are directly generated. As a consequence, financing sources could be interpreted in two ways: as types of revenues, and as institutional units.

For the analysis of revenue-raising, three viewpoints can be taken: where the flows originate; where the flows go; and what is the nature of the flows. Understanding the nature of the flows is of importance from the perspective of both health and public finance policy. For example, the classification of the FS should make it possible to distinguish between public and private funding of health care finance. Understanding how resources are raised by financing schemes is important for many countries, as many health systems are struggling with the issue of funding. They either want to increase total funding or to use it in a better way, keeping in mind that an increase in funding needs to be both sustainable and equitable. There is a growing need for policy makers to inform their decision-making with respect to both existing and advocated mechanisms for financing the health care system. The classification of revenues of financing schemes is suitable for tracking the collection mechanisms of a financing framework. Furthermore, the new classification makes it possible to analyse the contribution of the institutional units to health financing. ${ }^{1}$

The classification of revenues also makes an adequate interpretation of public and private finance possible. It has been recognised that there is no one-to-one correspondence between the public-versus-private split regarding institutional units of the health system and the public-versus-private split regarding the funds used for financing health care. This is a source of ambiguity for the interpretation of public and private. For example, "households", as an institutional sector, belongs to the private sector, while households contribute to both public and private funds (e.g. the funds of social health insurance and the funds of voluntary health insurance, and, of course, households are the main source of government revenues more generally). Social health insurance contributions paid by households are considered as elements of public finance, and voluntary health insurance fees paid by households are considered as elements of private finance. ${ }^{2}$ This is consistent with public finance logic, as "social security taxes" are considered part of public finance for 
the purposes of public deficit/surplus calculations. In other words, social insurance contributions are part of a government's "fiscal space".

Nevertheless, understanding the total contribution of each institutional sector of the economy is also key information, as this indicates the respective financial burden of each sector. For this reason, it is proposed to include institutional sectors (using the SNA categories) as memorandum items in the classification of FS, which would sum up the revenues for each institutional sector from the types of revenues. ${ }^{3}$

Table 8.1. Comparison of FS in SHA 2011 with the Producers Guide

\begin{tabular}{|c|c|c|}
\hline & Revenues of financing schemes under SHA 2011 & $\begin{array}{l}\text { Financing sources under the Producers } \\
\text { Guide (PG) }\end{array}$ \\
\hline Definition of ICHA-FS & $\begin{array}{l}\text { Revenues of financing schemes (e.g. government } \\
\text { revenues, social insurance contributions, etc.). }\end{array}$ & $\begin{array}{l}\text { Institutional units of the economy whose resources } \\
\text { are mobilised and managed by financing schemes } \\
\text { (government, corporations, etc.) }\end{array}$ \\
\hline $\begin{array}{l}\text { Key information provided by the FS } \\
\text { classification }\end{array}$ & $\begin{array}{l}\text { "How" revenues are mobilised by financing } \\
\text { schemes (type of transactions ) }\end{array}$ & $\begin{array}{l}\text { "From whom" revenues are collected by } \\
\text { financing schemes }\end{array}$ \\
\hline Additional informationneeded & $\begin{array}{l}\text { "From whom" revenues are collected (sub- } \\
\text { categories of the proposed classification) }\end{array}$ & "How" revenues are mobilised \\
\hline
\end{tabular}

Source: IHAT for SHA 2011.

\section{Comparison of the concept of revenues of financing schemes with financing sources under the Producers Guide}

The main advantages of the revenue of schemes classification are as follows:

- It provides comprehensive information about revenue-raising (how and what type of revenues are raised by the financing schemes and - in combination with information on institutional units - from which institutional sectors of the economy).

- It allows for a sound interpretation of the structure of "public" and "private" finance; more precisely, by modifying the major expenditure aggregates in a way that better reflects the current health financing arrangements. The proposed aggregates are: "Public and compulsory private funds spent on health care" and "Voluntary private funds spent on health care" (see Chapter $7^{4}$ ).

- It makes it possible to analyse the issue of multiple layers of financing and the issue of who bears the burden of financing the schemes (see Table 8.4).

\section{Definition of revenues of health care financing schemes}

Revenue is an increase in the funds of a health care financing scheme, through specific contribution mechanisms. The categories of the classification are the particular types of transaction through which the financing schemes obtain their revenues.

The objective of this classification is to group types of revenues ${ }^{5}$ of health financing schemes into mutually exclusive classes. If appropriate, the revenue category has subcategories that are defined according to who (or which institutional sector) provides the given revenue. (For example, voluntary prepayment as a category of Revenues of financing schemes has the sub-categories: voluntary prepayments from households, voluntary prepayments from employers and so on.)

Revenues can also be in-kind transfers (for example, in-kind foreign assistance to government financing schemes). 
In several countries, social security agencies or private insurance companies act as financing agents not only for health insurance but also, for example, for pensions, unemployment and housing. In these cases, only their health-relevant revenues should be taken into account. This requires different adjustment procedures, and hence the development of guidelines. In particular, when such complex institutions serve as financing agents, analyses of their deficits and surpluses require careful examination,. The deficits and surpluses of health financing schemes may be highly influenced by the assumption of how to calculate "health-related revenues".

Table 8.2 presents the classification of revenues of financing schemes, and the following paragraphs provide explanations of some of the major categories.

\section{Explanatory notes to the ICHA-FS classification of revenues of health care financing schemes}

\section{FS.1 Transfers from government domestic revenues}

This item refers to the funds allocated from government domestic revenues for health purposes. Countries with decentralised public administration (and decentralised collection of public revenues) may want to show the role of central and local government in providing revenues of health financing schemes. These countries may wish for national purposes to create sub-categories under FS.1.1 to FS.1.4 (see Table 8.5).

\section{FS.1.1 Internal transfers and grants}

This item refers to transfers within the central government and - in countries with decentralised tax system (where regional/local government also collects taxes) - transfers within regional/local governments, as well as grants from central to local government. Internal transfers are the key components of the budget of the government health financing schemes (HF.1.1). As Table 8.3 shows, government schemes may have other types of revenues, such as other domestic revenues (FS.6, for example, donations) and foreign revenues (FS.7).

- Includes: revenues allocated to government schemes (FS.1.1), which may be an internal transfer within the same level of government or a transfer between central and local governments. Includes: the budget of national health services; funds allocated to central government health programmes in countries with social insurance; etc.

This item includes grants received from another domestic government unit.

- Includes: grants by central government to local government financing schemes; revenues allocated to specific government employees schemes (see definition of government health financing schemes in Chapter 7); etc.

- Excludes: social insurance contributions paid by government as an employer. (This is accounted under FS.3.2).

\section{FS.1.2 Transfers by government on behalf of specific groups}

This item refers mainly to payments to social health insurance. In several countries, the government pays on behalf of certain population groups (for example, children, the elderly, certain groups of the unemployed and so on) to guarantee insurance coverage for these groups. 
Table 8.2. Classification of revenues of health care financing schemes

\begin{tabular}{|c|c|}
\hline Code & Description \\
\hline FS.1 & Transfers from government domestic revenue (allocated to health purposes) \\
\hline FS.1.1 & Internal transfers and grants \\
\hline FS 1.2 & Transfers by government on behalf of specific groups \\
\hline FS.1.3 & Subsidies \\
\hline FS.1.4 & Other transfers from government domestic revenue \\
\hline FS.2 & Transfers distributed by government from foreign origin \\
\hline FS.3 & Social insurance contributions \\
\hline FS.3.1 & Social insurance contributions from employees \\
\hline FS.3.2 & Social insurance contributions from employers \\
\hline FS.3.3 & Social insurance contributions from self-employed \\
\hline FS.3.4 & Other social insurance contributions \\
\hline FS.4 & Compulsory prepayment (other than FS.3) \\
\hline FS.4.1 & Compulsory prepayment from individuals/households \\
\hline FS.4.2 & Compulsory prepayment from employers \\
\hline FS.4.3 & Other compulsory prepaid revenues \\
\hline FS.5 & Voluntary prepayment \\
\hline FS.5.1 & Voluntary prepayment from individuals/households \\
\hline FS.5.2 & Voluntary prepayment from employers \\
\hline FS.5.3 & Other voluntary prepaid revenues \\
\hline FS.6 & Other domestic revenues n.e.c. \\
\hline FS.6.1 & Other revenues from households n.e.c. \\
\hline FS.6.2 & Other revenues from corporations n.e.c. \\
\hline FS.6.3 & Other revenues from NPISH n.e.c. \\
\hline FS.7 & Direct foreign transfers \\
\hline FS.7.1 & Direct foreign financial transfers \\
\hline FS.7.1.1 & Direct bilateral financial transfers \\
\hline FS.7.1.2 & Direct multilateral financial transfers \\
\hline FS.7.1.3 & Other direct foreign financial transfers \\
\hline FS.7.2 & Direct foreign aid in kind \\
\hline FS.7.2.1 & Direct foreign aid in goods \\
\hline FS.7.2.1.1 & Direct bilateral aid in goods \\
\hline FS.7.2.1.2 & Direct multilateral aid in goods \\
\hline FS.7.2.1.3 & Other direct foreign aid in goods \\
\hline FS.7.2.2 & Direct foreign aid in kind: services (including TA) \\
\hline FS.7.3 & Other direct foreign transfers (n.e.c.) \\
\hline \multicolumn{2}{|l|}{ Memorandum items } \\
\hline \multicolumn{2}{|l|}{ Reporting items } \\
\hline FS.RI.1 & Institutional units providing revenues to financing schemes \\
\hline FS.RI.1.1 & Government \\
\hline FS.RI.1.2 & Corporations \\
\hline FS.RI.1.3 & Households \\
\hline FS.RI.1.4 & NPISH \\
\hline FS.RI.1.5 & Rest of the world \\
\hline FS.RI.2 & Total foreign revenues (FS.2 +FS.7) \\
\hline \multicolumn{2}{|l|}{ FS Related items } \\
\hline FSR.1 & Loans \\
\hline FSR.1.1 & Loans taken by government \\
\hline FSR.1.2 & Loans taken by private organisations \\
\hline FSR.2 & Aid in kind at donor value \\
\hline
\end{tabular}

Source: IHAT for SHA 2011. 
The government may buy voluntary insurance covering the co-payments for the poor. In this case, voluntary insurance fees paid by the government are also accounted under this category.

- Excludes: contributions paid by the government as employer.

\section{FS.1.3 Subsidies}

This item refers to the funds allocated from government domestic revenues to financing schemes operated by institutional units other than government units or NPISH.

- Includes: subsidies for compulsory or voluntary health insurance schemes (managed by private insurance companies). Tax allowances provided to households who buy private health insurance may be accounted under this category.

\section{FS.1.4 Other transfers from government domestic revenues}

This item includes government transfers to NPISH financing schemes. These transfers usually are intended to cover the costs of NPISH activities or to provide the funds out of which NPISH may make current transfers to households (e.g. for foreign treatment of sick children). This category also covers transfers in kind.

\section{FS.2 Transfers distributed by government from foreign origin}

Transfers originating abroad (bilateral, multilateral or other types of foreign funding) that are distributed through the general government are recorded here. For the financing scheme receiving these funds, the provider of the fund is the government, but the fund itself is from a foreign origin. The origin of the revenue can only be registered at the level of the transaction of the revenue.

Transactions involving revenues from foreign entities channelled via government may take the following major forms:

- Foreign financial revenues earmarked for health. These revenues are usually grants by international agencies or foreign governments donated to the government, or voluntary transfers (donations) by foreign NGOs or individuals to the government. Governments may use these donations to fund governmental or NPISH health financing schemes.

- Non-earmarked foreign revenues. These revenues are grants and voluntary transfers (other than grants) received by the government without detailed specification of their use by the foreign agency.

\section{FS.3 Social insurance contributions}

Social health insurance contributions are receipts either from employers on behalf of their employees or from employees, the self-employed or non-employed persons on their own behalf that secure entitlement to social health insurance benefits. Sub-categories of social insurance contributions are classified by the type of institutional units that pay the social insurance contribution on behalf of the insuree.

This category excludes social insurance contributions paid by the government on behalf of specific groups (which are recorded in FS.1.2). It also excludes "imputed social insurance contributions" (which are under FS.6). 


\section{FS.3.1 Social insurance contributions from employees}

This item covers the social health insurance contributions received from households. In a technical sense, employees' contributions are either paid directly by employees or are deducted from employees' wages and salaries and transferred on their behalf by the employer.

\section{FS.3.2 Social insurance contributions from employers}

This item comprises the social health insurance contributions received from employers. Employers' contributions are paid directly by employers. This includes insurance contributions by the government as an employer, if public employees participate in the general social health insurance scheme (if there is no specific scheme for government employees).

For national purposes, countries may want to create sub-categories by distinguishing the different institutional types of employers, such as government units, public and private corporations, and NPISH. In this case, similar sub-categories under FS.3.1 should be created.

In a macroeconomic sense, both employees' and employers' social insurance contributions are part of the compensation of employees (elements of labour costs). However, for health policy analysis, it is useful to make a distinction between them.

\section{FS.3.3 Social insurance contributions from self-employed}

This item covers the social health insurance contributions received from selfemployed persons.

\section{FS.3.4 Other social insurance contributions}

This item refers to revenues of social health insurance schemes (HF.2) other than those classified under FS.1.2 and FS.3.1 to 3.3. It includes, for example, health insurance contributions paid by pension insurance funds on behalf of retired persons.

\section{FS.4 Compulsory prepayment (other than FS.3)}

This includes compulsory private insurance premiums and payments to compulsory MSAs. Compulsory private insurance premiums are payments received from the insuree or other institutional units on behalf of the insuree that have been mandated by government and secure entitlement to benefits of compulsory health insurance schemes. Under compulsory private health insurance, all residents (or defined groups of residents) are obliged to purchase a health insurance policy. The law may also define the rules for insurance premiums, for example, to oblige insurance companies to apply community rating.

Sub-categories of compulsory prepayment (other than FS.3) are classified by the type of institutional units paying the revenues, as follows:

- Compulsory prepayment from individuals/households (FS.4.1);

- Compulsory prepayment from employers (FS.4.2);

- Other compulsory prepaid revenues (FS.4.3), for example, compulsory private insurance premiums received from institutional units other than households and employers. 


\section{FS.5 Voluntary prepayment}

This includes voluntary private insurance premiums. Voluntary insurance premiums are payments received from the insuree or other institutional units on behalf of the insuree that secure entitlement to benefits of the voluntary health insurance schemes. Subcategories of voluntary prepayment are classified by the type of institutional units paying the revenues, as follows:

- Voluntary prepayment from individuals/households (FS.5.1);

- Voluntary prepayment from employers (FS.5.2);

- Other voluntary prepaid revenues (FS.5.3) (for example, received from institutional units other than households and employers).

\section{Methodological note}

As already discussed, there exists a variety of types of voluntary health insurance across countries. Accordingly, the rules for setting their premiums also differ. The main types are: risk-rated individual premiums; group-rated premiums; and community-rated premiums. While there is no intention to use such detailed categories for international data collection, countries may find it useful for their national health accounts to define sub-categories of voluntary insurance premiums according to these types.

\section{FS.6 Other domestic revenues n.e.c.}

This category includes domestic revenues of financing schemes not included under FS.1 to FS.5. Sub-categories are defined according to the institutional units that provide the voluntary transfers:

- Other revenues from households n.e.c. (FS.6.1);

- Other revenues from corporations n.e.c. (FS.6.2);

- Other revenues from non-profit institutions n.e.c. (FS.6.3).

\section{FS.6.1 Other revenues from households n.e.c.}

This category includes the sources of households' out-of pocket payments, as well as any voluntary transfers from households to health financing schemes, other than those classified under FS.5, for example, donations to NPISH health programmes.

\section{FS.6.2 Other revenues from corporations n.e.c.}

This category includes the resources of corporations devoted to health purposes, other than those included in FS.3 to FS.5. This category is the main financing source of the Enterprise financing schemes (HF.2.3). Enterprise financing schemes primarily include arrangements where enterprises provide or directly finance health services for their employees (such as occupational health services), without the involvement of an insurance-type scheme.

The SNA uses the term "Imputed social contributions" for social benefits that are provided directly by employers without creating a special fund. These revenues are accounted under this category of SHA 2011.

This also includes voluntary donations from corporations. A special example is as follows. Some health care providers (e.g. hospitals) may earn money (interest) by keeping their funds in banks. The health care providers may spend this extra income on providing 
health care. In this case, the financing scheme is: HF.2.3.2 Health care providers financing scheme (which is a sub-category of Enterprise financing schemes); the revenue category is: FS.6.2 Other revenues from corporations. ${ }^{6}$

Similarly, private insurance corporations may use interest revenue for activities related to the provision of health insurance. These receipts have to be included as revenues for health care only when they are used to fund health services (including the administration of health insurance). SHA does not explicitly distinguish between funded and unfunded systems, because funded systems could be characteristic of various types of schemes including social insurance. The recording of revenues from interest should always be part of FS.6.2.

\section{FS.7 Direct foreign transfers}

The main ways that revenues from foreign entities directly (via transfers) received by health financing schemes may be transacted are:

- Direct foreign financial revenues earmarked for health. These revenues are usually grants by international agencies or foreign governments, or voluntary transfers (donations) by foreign NGOs or individuals that contribute directly to the funding of domestic health financing schemes;

- Direct foreign aid in kind (health care goods and services).

Current transfers for international co-operation in cash or in kind include emergency aid after natural disasters. This should be distinguished from capital transfers of a similar kind, which would fall under capital formation.

Two subcategories of direct foreign revenues are defined:

- Financial transfers or foreign aid in kind (goods or services);

- Bilateral, multilateral or other transfers.

The detailed sub-categories of foreign revenues are as follows: direct bilateral financial transfers, direct multilateral financial transfers, other direct foreign financial transfers; direct bilateral aid in goods, direct multilateral aid in goods, other direct foreign aid in goods; and direct foreign aid in services (including TA).

Note: If donations or types of assistance from a foreign source are channelled through government or government agencies, these flows are recorded under FS.2 and not under FS.7. FS.7 is restricted to the direct foreign contributions received by the various schemes. [Direct (earmarked) foreign transfers to governmental health financing schemes are also recorded as FS.7.]

\section{Memorandum items}

\section{Loans}

See the section on the "Treatment of loans". Countries may want to report subcategories of loans, such as their origin, domestic or external, according to Table 8.3. Other breakdowns could be by maturity (one year, more years) or by instruments, taking into account the total net borrowing (currency and deposits, securities other than shares, excluding financial derivatives and loans). 
Table 8.3. Suggested reporting of loans as memorandum items to the FS classification

\begin{tabular}{cl}
\hline Code & Description \\
\hline FSR.1 & Loans \\
FSR.1.1 & Loans taken by government \\
FSR.1.1.1 & Loans from international organisations \\
FSR.1.1.1.1 & Concessional \\
FSR.1.1.1.1 & Non-concessional \\
FSR.1.1.2 & Other loans taken by government \\
FSR.1.2 & Loans taken by private organisations \\
\hline
\end{tabular}

Source: IHAT for SHA 2011.

\section{Institutional units}

The second group of memorandum items consists of the institutional units that provide revenues to financing schemes. Included are:

- Government;

- Corporations;

- Households;

- NPISH;

- Rest of the world.

These categories allow the estimation and analysis of the revenue collection transactions from the perspective of the institutional units of the economy from which the health financing schemes receive their revenues. (The section "SHA tables on revenue collection" provides a more detailed discussion.)

This (revenue-provider) role of the institutional units should be distinguished from the role of institutional units as agencies that collect funds. For example, social insurance contributions provided by households and corporations to social insurance schemes may be collected by a government agency, for example, the National Tax Authority in a country. In this case the National Tax Authority is the institutional unit collecting the funds. However, it does not appear explicitly in the classification of revenues of health financing schemes. The revenues concerned are accounted under FS.3 and also recorded under Households and Corporations.

\section{Specific conceptual issues}

\section{Transfers from government revenues}

The role of government in revenue-raising requires special consideration. In a macroeconomic sense, there are two main ways that financing schemes raise their revenues:

- Revenues are directly received from the primary owners of income: households, corporations and the rest of the world. The amount of revenues is decided by regulation, contracts or decisions made by the primary owners of income;

- Revenues are received as the result of the allocation of the general revenues of the government. First, the government raises general revenues for their overall activities from the primary owners of income, then it allocates the revenues among the different public spending areas, including health financing schemes. 
In the case of non-earmarked revenues of the state budget, there is no direct link between the types of government revenues ${ }^{7}$ (income tax, VAT, corporate taxes, grants, sales, etc.) and the types of spending area (education, health, etc.). It is the budget decision that determines the revenues for the government health financing schemes. Therefore FS.1 "Transfers from government domestic revenues" refers to government domestic revenues allocated to health purposes and FS.2 to transfers by government from foreign sources.

It is clear that the main primary owners of income are households, corporations and the rest of the world. ${ }^{8}$ However, due to its decision-making role concerning the allocation of its general revenues, it is important to show the role of the government as the institutional unit that allocates revenues to health financing schemes.

In order to provide a transparent picture of the role of government, the sub-categories of FS.1 distinguish between internal transfers (for example, allocations from the central government budget to the Ministry of Health and grants to local governments); a contribution by government on behalf of specific groups (for example, on behalf of the children, the elderly, the inactive poor, etc.); subsidies (e.g. to employers buying health insurance for their employees); and other transfers from government domestic revenues (such as for NPISH). The information on social insurance contributions paid by the government on behalf of certain non-active population groups is increasingly important for policy analysis in countries where the social insurance scheme plays the major role in financing the health services.

Figure 8.1 displays the allocation of domestic and foreign revenues of government to financing schemes and subcategories of FS.1.

\section{Figure 8.1. A simplified display of transfers from government revenues to financing schemes}

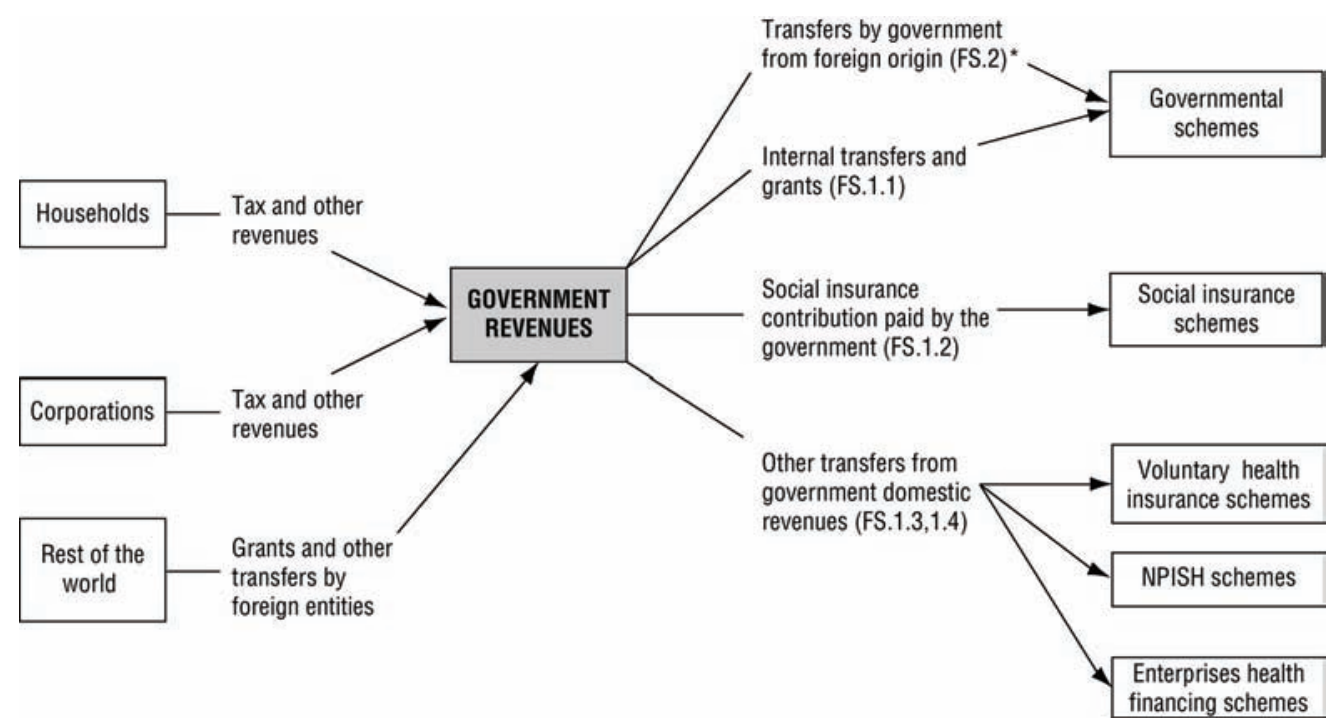

* It is assumed that FS.2 is used for governmental schemes but other schemes are not excluded for receiving transfers from foreign origin via government.

Source: IHAT for SHA 2011.

In some countries, tax earmarked for health may play a considerable role. In this case, it is possible first to distinguish general tax, earmarked tax and other government revenues as sub-categories of FS.1, and then under each of these to create the following 
sub-categories: internal transfers and grants; transfers by government on behalf of specific groups; and subsidies and other transfers.

\section{FSR.1 Treatment of loans}

By definition, loans are changes in financial assets or liabilities (that is, loans are not included in revenues). Loans are generally taken to cover the state budget expenditure that is not balanced by domestic revenues. There are also health sector specific loans, usually for investments in the health sector. It is proposed to present the amount of loans "used" in the given accounting period as memorandum items. (This amount obviously may be different from the loans "taken" in the same period.) For some lower-income countries it may be important to show the role of foreign loans in financing the health system. In these cases, it is proposed to apply the "Statement of Government Operation" presented in GFS for the health sector; that is to prepare a Statement of Government Health sector-related Operation. (Separate guidelines on implementation will provide more details.)

This Manual does not address general public finance issues, such as, for example, debt cancellation or debt relief. Those issues can be analysed using the GFS Manual. However, countries involved in debt cancellation, either as a debtor or creditor, may need to track those resources. Further analysis of this issue is discussed at the end of this chapter.

As already discussed in Chapter 7, sectoral accounts provide possible tools to account for the deficits or surpluses of health financing schemes (and financing agents) and for any loans or other financial instruments taken to balance the deficit. Sectoral accounts show how deficits or net borrowing are covered by the net lending of other sectors of the economy or by the rest of the world. Deficits and surpluses with institutional units of the same sector are consolidated. ${ }^{9}$

Households may also take loans to pay for health care. This is, however, disregarded and not included in the memorandum item, as estimating it does not seem feasible.

\section{Valuation of in kind assistance and technical support}

According to the GFS, grants in kind should be valued at current market prices. If market prices are not available, then the value should be the explicit costs incurred in providing the resources or the amounts that would be received if the resources were sold. In some cases, the donor and the recipient may view the value quite differently. SHA 2011 deviates from the GFS and records the value applied by the recipients as the health expenditure. In these cases, the valuation from the viewpoint of the donor is, however, included as a memorandum item (FSR.2), in order to make the difference between the valuation by the donor and the recipient transparent.

\section{SHA tables on revenue collection}

\section{Revenues of health financing schemes by types of revenues (HFxFS table)}

The table "Revenues of health financing schemes by types of revenues" (HFxFS) shows the revenue structure of the health financing schemes: the types of transactions through which resources are channelled from the institutional units of the economy to financing schemes (see Table 15.4 in Chapter 15). 


\section{Revenues of health financing schemes by institutional units and types of revenues}

The appropriate presentation of the revenues of financing schemes by the types of revenues and by the institutional units of the economy (providing the revenues) requires a double-entry accounting. This also makes it possible to show the final burden of health financing on institutional units (the last line "Net contribution" in the upper part of Table 8.4).

Table 8.4. Revenues of health financing schemes by Institutional units and types of revenues

\begin{tabular}{|c|c|c|c|c|c|c|c|c|c|c|c|c|c|c|c|}
\hline \multicolumn{14}{|c|}{ Health-specific revenues and expenses of institutional sectors of the economy } & & \multirow{8}{*}{ 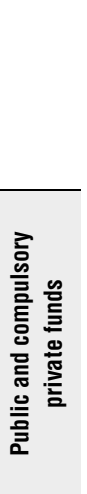 } \\
\hline \multirow{2}{*}{$\begin{array}{l}\text { Institutional } \\
\text { sectors of the } \\
\text { economy }\end{array}$} & & \multicolumn{2}{|c|}{$\begin{array}{c}\text { General } \\
\text { government }\end{array}$} & \multicolumn{2}{|c|}{ Corporations } & \multicolumn{2}{|c|}{ Households } & \multicolumn{2}{|c|}{ NPISH } & \multicolumn{2}{|c|}{$\begin{array}{c}\text { Rest of the } \\
\text { world }\end{array}$} & \multicolumn{2}{|c|}{ Total } & & \\
\hline & & $\mathrm{R}$ & $\mathrm{E}$ & $\mathrm{R}$ & $\mathrm{E}$ & $\mathrm{R}$ & $\mathrm{E}$ & $\mathrm{R}$ & $\mathrm{E}$ & $\mathrm{R}$ & $\mathrm{E}$ & $\mathrm{R}$ & $\mathrm{E}$ & & \\
\hline FS.1.1 & Internal transfers and grants & 200 & -150 & & & & -200 & & & & & 200 & -350 & 150 & \\
\hline FS.1.2 & $\begin{array}{l}\text { Contribution payment on behalf of specific } \\
\text { groups }\end{array}$ & & -30 & & & & & & & & & & -30 & 30 & \\
\hline FS.1.4 & $\begin{array}{l}\text { Other transfers from government domestic } \\
\text { revenues }\end{array}$ & & -20 & & & & & 10 & & & & 10 & -20 & 10 & \\
\hline FS.3 & Social insurance contributions & & $<$ & & -100 & & -100 & & & & & 0 & -200 & 200 & \\
\hline FS.4 & $\begin{array}{l}\text { Compulsory prepayment } \\
\text { (other than FS.2) }\end{array}$ & & & & & & & & & & & 0 & 0 & & \\
\hline FS.5 & Voluntary prepayment & & & & & & -10 & & & & & 0 & -10 & 10 & \\
\hline FS.6 & Other domestic revenues n.e.c. & & & & -5 & & -50 & & -10 & & & 0 & -65 & 65 & 类 \\
\hline \multirow[t]{3}{*}{ FS.7 } & Foreign revenues & & & & & & & & & & -50 & 0 & -50 & 50 & Фِ \\
\hline & Total & 200 & -200 & 0 & -105 & 0 & -360 & 10 & -10 & 0 & -50 & 210 & -725 & & \\
\hline & Net contribution & & $\mathbf{0}$ & & -105 & & -360 & & 0 & & -50 & & -515 & & \\
\hline \multicolumn{14}{|c|}{ Revenues of financing schemes } & & \\
\hline HF.1.1 & Government financing schemes & & 150 & & & & & & & & 20 & & 170 & & \\
\hline HF.1.2 & Social health insurance & & 30 & & 100 & & 100 & & & & & & 230 & & \\
\hline$\stackrel{\rightleftarrows}{E}$ HF.1.3 & Compulsory private health insurance & & & & & & & & & & & & 0 & & \\
\hline 总 HF.2.1 & Voluntary health insurance & & & & & & 10 & & & & & & 10 & & \\
\hline OPF.2.2 & Non-profit Institutions schemes & & 10 & & & & & & 10 & & 30 & & 50 & & \\
\hline 壱 HF.2.3 & Enterprises schemes & & & & 5 & & & & & & & & 5 & & \\
\hline \multirow[t]{2}{*}{ 语 HF.3 } & Household out-of-pocket payments & & & & & & 50 & & & & & & 50 & & \\
\hline & Total & & 190 & & 105 & & 160 & & 10 & & 50 & & 515 & & \\
\hline
\end{tabular}

Source: IHAT for SHA 2011.

The upper part of Table 8.4 presents simplified T-accounts for the institutional units of the economy. These T-accounts show the revenues (R) and expenses (E) of institutional units related to health financing.

The table contains an important simplification: the resources provided by the RoW (that is to say, expenses of RoW) are accounted as revenues of the "final destination", even if the fund goes through the government budget. However, if necessary, it is possible to prepare a table that shows all government revenues (domestic and foreign together) and distinguishes funds by RoW that go through the government budget as well as the other RoW funds.

The numbers in the bottom part of the table present the revenues of financing schemes. For example, the bottom part shows that the social health insurance scheme 
collects 30 units from the government, and the upper part (-30) shows that the government paid this as an insurance contribution (on behalf of certain groups of the population).

An institutional unit may provide resources:

- Directly to a health financing scheme, e.g. social insurance contribution by corporations to social health insurance (100 in Table 8.4); and

- Indirectly contribute to the revenues of a health financing scheme. In this case, the institutional unit provides resources to another institutional unit from which a health financing scheme collects revenues. (As mentioned, however, the table provides this information only for domestic revenues.) For example, the government provides transfers of 20 units to NPISH, of which 10 units go directly to NPISH financing schemes, while 10 units go to NPISH that do not purchase health services, but only collect resources and transfer them to NPISH purchasing services.

The total in the bottom part of the table shows the last phase of revenue collection, i.e. from which institutional units the financing schemes directly raise their revenues. For example, the general government provides 190 units to the different financing schemes together.

The total in the upper part of the table shows the primary sources of health finance. It can be seen that the government only redistributed its general domestic revenues to the different health financing schemes and to other institutional units that provide revenues to health financing schemes. Hence, this table is appropriate to show the multiple layers of domestic revenues.

Furthermore, based on the types of revenues, it is possible to distinguish the domestic public and compulsory private funds and private funds and foreign revenues used for health finance (see the last two columns).

\section{Additional tools}

\section{Sub-categories of government domestic revenue}

As already mentioned, countries with decentralised public administration (and decentralised collection of public revenues) may, for national purposes, wish to show the role of the central and local governments in providing the revenues of health financing schemes. These countries may create sub-categories under FS.1.1 to FS.1.4 (see Table 8.5).

\section{Tool for the analysis of the sources of household out-of-pocket payments}

Countries with very large proportions of OOP payments, such as many countries in Africa and Asia, may be interested in identifying the sources of OOP in detail.

A payment by the individual should not always be accounted as OOP, because it may be reimbursed by voluntary insurance or covered by the government (conditional cash transfers) or by an NGO. In these cases, the payment for the health care is technically made by the household, but not from the household's "pocket", nor from the household's primary income or savings. Therefore, the first step is to deduct those items that should be accounted as other than OOP, such as government schemes (conditional cash transfers), voluntary insurance, NPISH health financing schemes and RoW financing schemes.

The sources of OOP can only be the household's income (including remittances) or savings, or loans taken out by the household. 
Table 8.5. Sub-categories of Transfers from government domestic revenue

\begin{tabular}{ll}
\hline Code & Description \\
\hline FS.1 & Transfers from government domestic revenue (allocated to health purposes) \\
FS.1.1 & Internal transfers and grants \\
& Internal transfers within central government \\
& Internal transfers within regional/local government \\
& Grants from central government \\
FS.1.2 & Grants from regional/local government \\
& Payment by government on behalf of specific groups \\
FS.1.3 & Payment by central government \\
& Payment by regional/local government \\
& Subsidies from government \\
FS.1.4 & Subsidies from central government \\
& Subsidies from regional/local government \\
& Other transfers from government domestic revenue \\
& Other transfers from central government \\
\hline
\end{tabular}

Source: IHAT for SHA 2011.

The item "Conditional cash transfers" is perceived as a specific government health financing scheme (HF.1.1) and not as a source of OOP (see Chapter 7 for more detail).

Table 8.6 provides a possible tool for distinguishing household out-of-pocket payments as a financing scheme from total household payments for health care. Note: Countries obviously have to consider, on the one hand, the usefulness of this information, and on the other hand, whether the necessary information is available or can be made available at a reasonable cost.

Table 8.6. Accounting payments made by households for care under SHA 2011

\begin{tabular}{ll|l}
\hline Possible sources of payment for health care by households & \multicolumn{2}{c}{ Accounting under SHA 2011} \\
\hline Household's primary income (from employment or assets) & FS.6.1. Other revenues from households & HF.3 Household out-of-pocket payments \\
Remittance & FS.6.1 & HF.3 \\
Savings & FS.6.1 & HF.3 \\
$\quad$ Health savings accounts & FS.6.1 & HF.3 \\
$\quad$ Micro savings (for health) & FS.6.1 & HF.3 \\
$\quad$ Non-health-specific savings & FS.6.1 & HF.3 \\
Selling of goods/barter of goods & FS.6.1 & HF.3 \\
Loans & FS.6.1 & HF.3 \\
$\quad$ Bank loans & FS.6.1 & HF.3 \\
$\quad$ Micro-credit loans & FS.6.1 & HF.3 \\
$\quad$ Loans from traditional societies & FS.6.1 & HF.3 \\
(co-operatives) other than micro-credit & & HF.3 \\
Loans from friends/families & FS.6.1 & HF.1.1. Government schemes \\
Transfers & & HF.2.2 NPISH financing schemes \\
Conditional cash transfers from government & FS.1.1. & HF.4.2.2. Other voluntary RoW \\
\hline Transfers from national NGOs & FS.1.4.0ther transfers from government, \\
Transfers from foreign philanthropic sources & FS.6.0ther domestic revenues & Financing schemes \\
\hline
\end{tabular}

Source: IHAT for SHA 2011.

\section{Further analysis of external resources distributed by governments}

Health accounts expenditure does not include transactions in financial instruments; for certain types of analysis, such as development aid, loans that are given or received 
under preferential conditions must be accounted for. ${ }^{10}$ Any countries concerned may wish to analyse the use of specific classes of earmarked and non-earmarked funds. The main classes to highlight are the use of budget support, debt forgiveness or debt cancellation ${ }^{11}$ resources and the use of loans by health care government programmes. An additional table should be developed by countries to show how external resources are channelled through government funds to health care schemes. Specific guidelines to further analyse external resources distributed by governments are to be developed separately.

\section{Notes}

1. Whereas the interpretation of the FS as a set of institutional units does not allow an analysis of the types of health financing flows.

2. The FS categories, as presented in the Producers Guide (PG), do not show the types of transfers through which resources are channelled from institutional units to financing schemes. This can lead to a lack of transparency about important information, such as different forms of household finance. It does not provide a full picture of household involvement in health care financing. For example, classifying compulsory and voluntary household premiums separately provides useful information, as these imply different contribution and pooling/prepayment mechanisms. A classification of institutional units would not distinguish between a) a household's compulsory contributions (e.g. social insurance contributions of employees), which are part of the "fiscal space" and a government's public finance accounts, and hence should be treated as public expenditure, and b) voluntary prepayments (e.g. voluntary health insurance premiums), which are clearly private expenditure.

3. For example, all contributions by households (social insurance contributions, voluntary prepayments and other revenues from households (n.e.c.) would be added to evaluate total household contributions to the health system.

4. As noted in Chapter 7, by accounting separately for compulsory prepayments (for compulsory private insurance), analysts can in fact decide whether or not to count these as part of total public or total private health spending.

5. According to the GFS Manual, revenue is an increase in net worth resulting from a transaction, including both monetary and non-monetary transactions. Every transaction is either an exchange or a transfer. A transaction is an exchange if one unit provides a good, service, asset or labour to a second unit and receives a good, service, asset or labour of the same value in return. A transaction is a transfer if one unit provides a good, service, asset, or labour to a second unit without receiving simultaneously a good, service, asset, or labour of any value in return.

6. As the health care providers generate the extra resource - from the interest - and voluntarily decide to use it on patient care. In fact, the "transfer" is an internal transfer within the health care providers.

7. It is beyond the scope of this Manual to examine the different types of general government revenues (e.g. the share of personal income tax, VAT, etc.). However, separate guidelines may be important for national analysis, in particular lower-income countries.

8. Here it is disregarded that government may also be the primary owner of certain income, e.g. from selling properties.

9. Consolidation is a method of presenting statistics for a set of units as if they constituted a single unit.

10. Financial transactions are not part of expenditure in the SNA; however, the need of specific analysis is also recognised in SNA 2008, 29.72.

11. It should be verified that the part of the debt recorded is related to the health care schemes. See definition and details in SNA 2008, 22.107 and related paragraphs: debt cancellation is the voluntary cancellation of all or part of a debt obligation within a contractual arrangement between a creditor and a debtor by the agreement between the parties and with the intention to convey a benefit. Debt forgiven may include all or part of the principal outstanding, inclusive of any accrued interest arrears and any other interest costs that have accrued. 


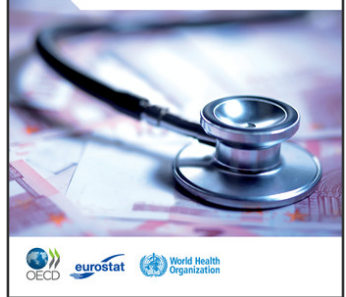

\section{From:}

A System of Health Accounts

2011 Edition

Access the complete publication at:

https://doi.org/10.1787/9789264116016-en

\section{Please cite this chapter as:}

OECD/World Health Organization/Eurostat (2011), "Classification of Revenues of Health Care Financing Schemes (ICHA-FS)", in A System of Health Accounts: 2011 Edition, OECD Publishing, Paris.

DOI: https://doi.org/10.1787/9789264116016-10-en

This work is published under the responsibility of the Secretary-General of the OECD. The opinions expressed and arguments employed herein do not necessarily reflect the official views of OECD member countries.

This document and any map included herein are without prejudice to the status of or sovereignty over any territory, to the delimitation of international frontiers and boundaries and to the name of any territory, city or area.

You can copy, download or print OECD content for your own use, and you can include excerpts from OECD publications, databases and multimedia products in your own documents, presentations, blogs, websites and teaching materials, provided that suitable acknowledgment of OECD as source and copyright owner is given. All requests for public or commercial use and translation rights should be submitted to rights@oecd.org. Requests for permission to photocopy portions of this material for public or commercial use shall be addressed directly to the Copyright Clearance Center (CCC) at info@copyright.com or the Centre français d'exploitation du droit de copie (CFC) at contact@cfcopies.com. 